\title{
The Decommissioning of the TA-42 Plutonium Contaminatei Incinerator Facility
}

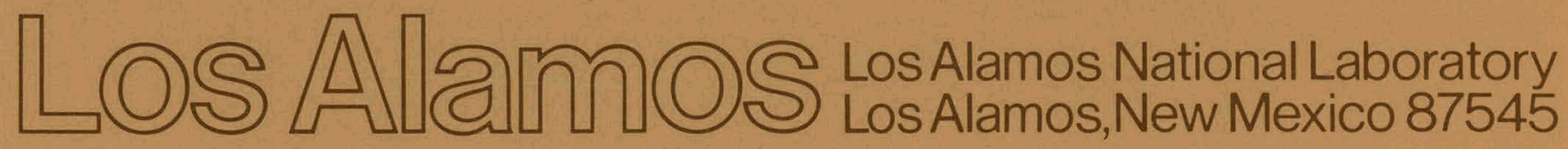




\section{DISCLAIMER}

This report was prepared as an account of work sponsored by an agency of the United States Government. Neither the United States Government nor any agency Thereof, nor any of their employees, makes any warranty, express or implied, or assumes any legal liability or responsibility for the accuracy, completeness, or usefulness of any information, apparatus, product, or process disclosed, or represents that its use would not infringe privately owned rights. Reference herein to any specific commercial product, process, or service by trade name, trademark, manufacturer, or otherwise does not necessarily constitute or imply its endorsement, recommendation, or favoring by the United States Government or any agency thereof. The views and opinions of authors expressed herein do not necessarily state or reflect those of the United States Government or any agency thereof. 


\section{DISCLAIMER}

Portions of this document may be illegible in electronic image products. Images are produced from the best available original document. 
This work was supported by the US Department of Energy, Division of Environmental Control Technology.

\section{DISCLAIMER}

This report was prepared as an account of work sponsored by an agency of the United States Government. Neither the United States Government nor any agency thereof, nor any of their employees, makes any warranty, express or implied, or assumes any legal liability or responsibility for the accuracy, completeness, or usefulness of any information, apparatus, product, or process disclosed, or represents that its use would not infringe privately owned rights. References herein to any specific commercial product, process, or service by trade name, trademark, manufacturer, or otherwise, does not necessarily constitute or imply its endorsement, recommendation, or favoring by the United States Government or any agency thereof. The views and opinions of authors expressed herein do not necessarily state or reflect those of the United States Government or any agency thereof. 


\section{The Decommissioning of the TA-42 Plutonium Contaminated Incinerator Facility}

Johnny R. Harper

Raymond Garde

DISCLAIMEN

This book was prepared as an account of work sponsored by an agency of the United States Government.
Neither the United States Government nor warranty. express or implied, or assumes any legal liability or responsibility for the accuracy, completentss. ar usetuness of any information, apparatus, product, or process disclosed, or commercial product. not necessarily constitute or imply its andorsement, rrademark, manufacturer, or otherwise, does 
THE DECOMMISSIONING OF THE TA-42 PLUTONIUM CONTAMINATED INCINERATOR FACILITY

\author{
by \\ Johnny R. Harper and Raymond Garde
}

\title{
ABSTRACT
}

During 1978, a plutonium $\left({ }^{239} \mathrm{Pu}\right)$ contaminated incinerator facility at the Los Alamos National Laboratory, Los Alamos, New Mexico, was decommissioned. The project involved dismantling the facility and burying the debris at an on-site radioactive solid waste disposal/storage area. Contaminated soil from the $5000 \mathrm{~m}^{2}$ area was also buried.

The facility was constructed in 1951 to incinerate ${ }^{239^{\circ}} \mathrm{Pu}$ contaminated wastes. It was later used as a degontamination facility. The major features included a $185-\mathrm{m}^{2}$ floor area control building, incinerator, cyclone dust collector, spray cooler, venturi scrubber, air filter bank, ash separator, and two 140 000-liter ash storage tanks.

Six-hundred cubic meters of deforis and $1200 \mathrm{~m}^{3}$ of soil contaminated with less than $10 \mathrm{nCi}{ }^{239} \mathrm{Pu}$ per gram of soil were buried at the Laboratory disposal area. Five cubic meters of $239 \mathrm{Pu}$ contaminated ash residues containing more than $10 \mathrm{nCi}$ ${ }^{239} \mathrm{Pu}$ per gram of waste were packaged and stored to meet the Department of Energy's 20-year retrievable storage criteria.

The operation consumed 80 work days and 5800 manhours at a cost of $\$ 150000$. This report presents the details concerning decommissioning procedures, the health physics, the wasle management, the environmental surveillance results, and a cost breakdown for the operation.

\section{INTRODUCTION}

In 1951 an incinerator facility was constructed at the Los Alamos National Laboratory, Los Alamos, New Mexico, to reduce the volume of plutonium contaminated wastes. The facility $(\mathrm{TA}-42)$ was enclosed in a $5000-\mathrm{m}^{2}$ fenced area (Fig. 1). It consisted of 
(a) a $185-\mathrm{m}^{2}$ floor area control office building (Fig. 2) housing a change room, a waste sorting area, and the feed port to the incinerator (Fig. 3);

(b) the incinerator and associated equipment (Figs. 4 and 5) such as blowers, cyclone dust collector, spray cooler, venturi scrubber, filter bank, and ash separator;

(c) two 140 000-liter ash storage tanks (Fig. 6); and

(d) a septic tank and tile field.

Several attempts at incinerating wastes with low levels of contamination indicated that the facility would require major modifications before it could handle the desired types of wastes. The facility was shut down in 1952. From 1957 until 1969, the facility was used for storage and decontamination of gloveboxes, vehicles, and other equipment. During the summer of 1969, an unsuccessful attempt was made to reactivate the incinerator to burn uncontaminated classified wastes. The facility then became a candidate for decommissioning. The residual contamination and the poor physical condition of the specialized building structure and equipment made it unattractive for any future beneficial occupancy.

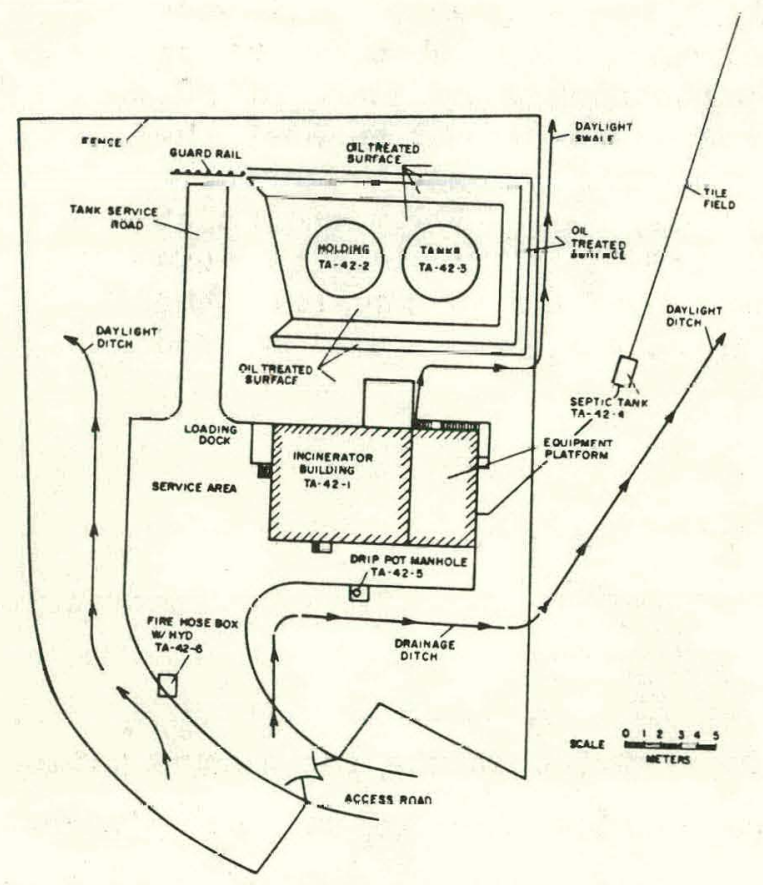

Fig. 1 .

Plot of fenced area.

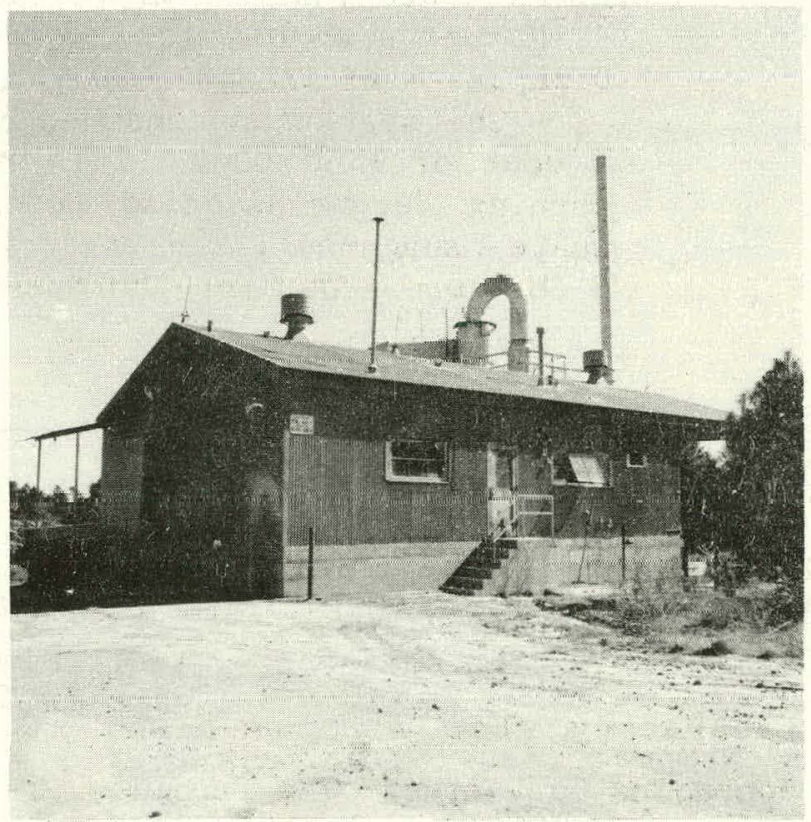

Fig. 2 .

Control office building. 


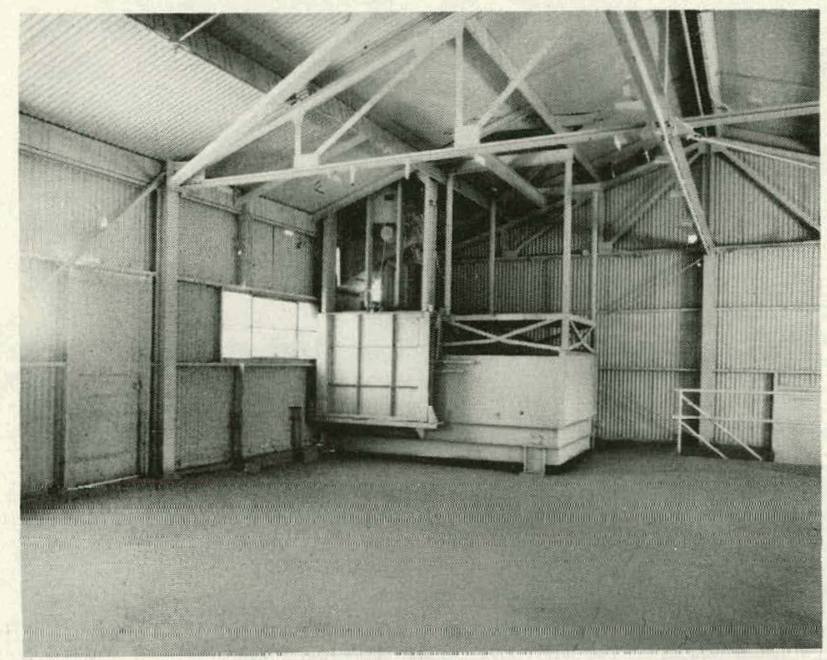

Fig. 3.

Incinerator feed port and interior of control office building after preliminary decontamination in 1975.

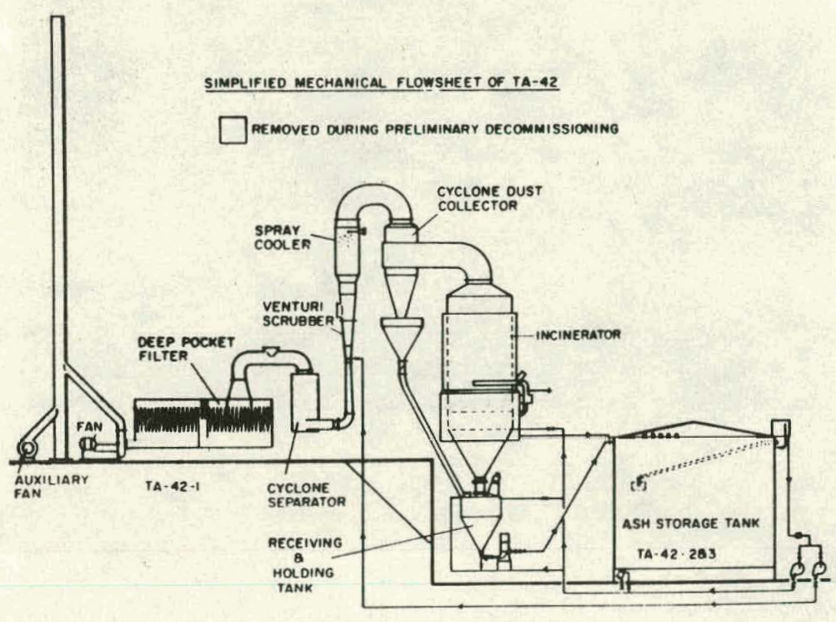

Fig. 5.

Incinerator and associated equipment.

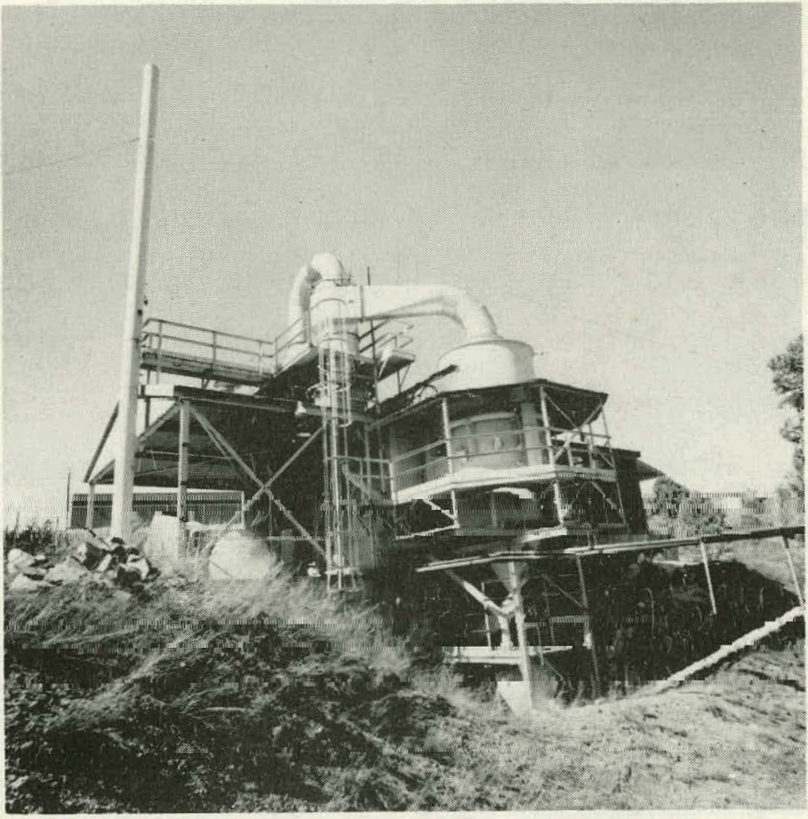

Fig. 4.

Incinerator and associated equipment.

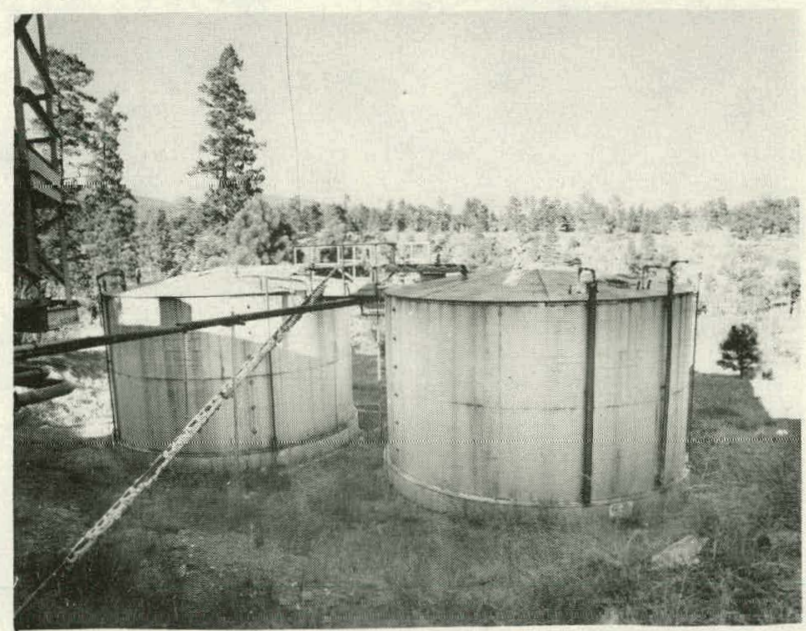

Fig. 6.

Ash storage tanks 
Preliminary contamination surveys with a Laboratory-developed portable phoswich system ${ }^{1}$ (Fig. 7) indicated detectable surface soil contamination within the fenced area, in the equipment, in the ash storage tanks, and in the septic tank and tile field effluent line. Most of the contamination present, excluding the contents of the ash storage tanks, was attributed to the decontamination operations.

On January 19, 1978, decommissioning work began with the removal of the galvanized sheeting from the walls and roof of the control building (Fig. 8). The sheeting was free of contamination due to preliminary decontamination efforts that took place in 1975. A crane was used during separation operations (Fig. 9) to remove the dust collector, spray cooler, venturi scrubber, ash separator, incinerator, and exhaust stack. Before removal, plastic sheeting was placed around highly contaminated items to prevent contamination releases, and

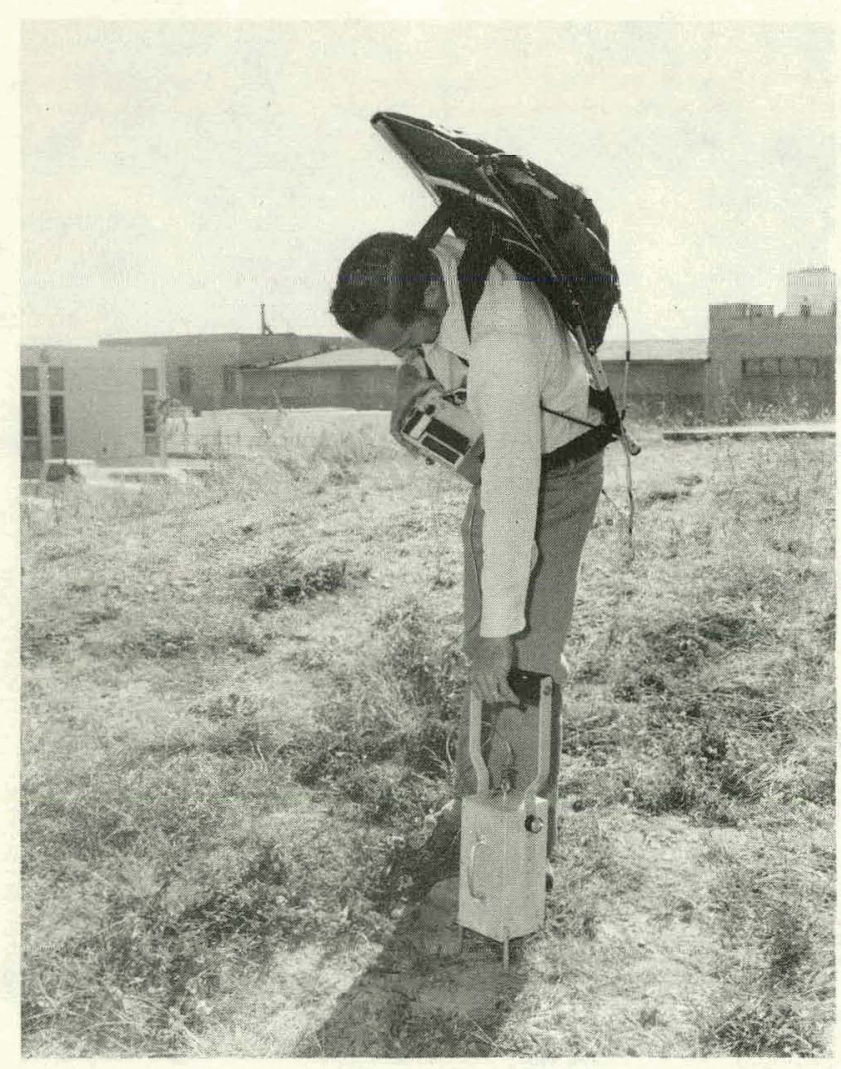

Fig. 7 .

Phoswich detector in field.

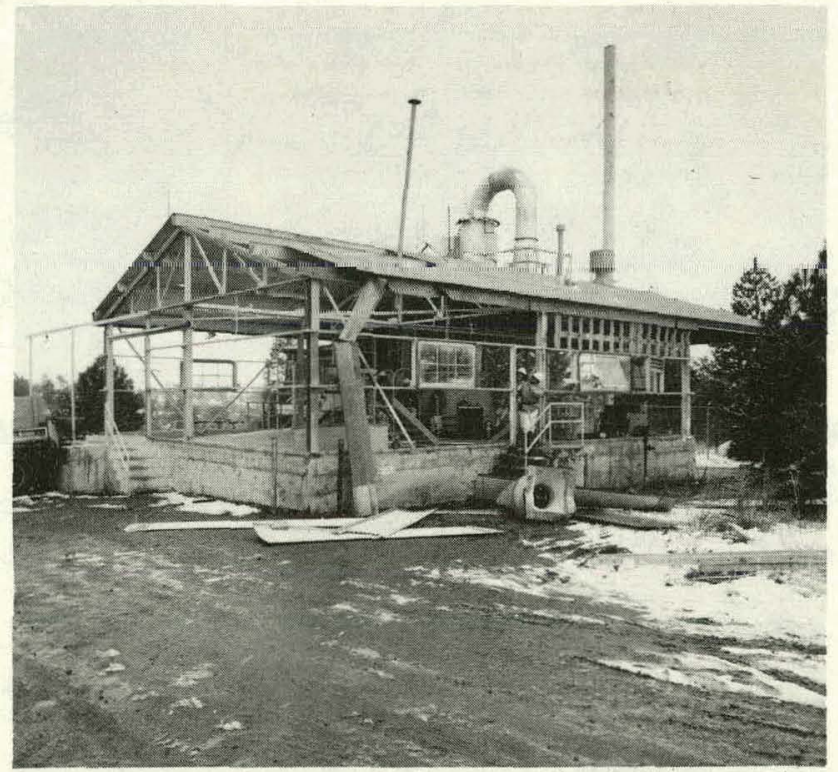

Fig. 8.

Removal of walls and roof. 
all contaminated openings were sealed with plastic and sheet metal as soon as it could be accomplished safely (Fig. 10). Internal alpha surface contamination levels were typically $45 \mathrm{dis} / \mathrm{s} / \mathrm{cm}^{2}$. Paint was liberally applied to fix loose contamination.

After removal of the structural steel (Fig. 11), the drain pipes in and under the building foundation were filled with hot asphalt to contain the contamination. The gross alpha activity on accessible portions of the pipes measured $22 \mathrm{dis} / \mathrm{s} / \mathrm{cm}^{2}$. The uncontaminated foundation was crushed with a crane and a steel ball (Fig. 12) and piled (Fig. 13) for loading into dump trucks.

Doors were cut on the sides of the two 140 000-liter ash storage tanks to permit personnel entry. One tank (Fig. 14) contained 2000 liters of dry sludge contaminated with $130 \mathrm{nCi}{ }^{239} \mathrm{Pu}$ per gram of sludge. The other (Fig. 15) contained 2600 liters of wet sludge with $1000 \mathrm{nCi}{ }^{239} \mathrm{Pu}$ per gram of sludge. A portable air blower, equipped with a high-efficiency particulate air (HEPA) filter and rated for $0.3 \mathrm{~m}^{3} / \mathrm{s}$, was used to provide ventilation during work inside the tanks.

The supernatant from the 4000-liter concrete septic tank (Fig. 16) was pumped into a tank and transported to the Laboratory's radioactive liquid waste

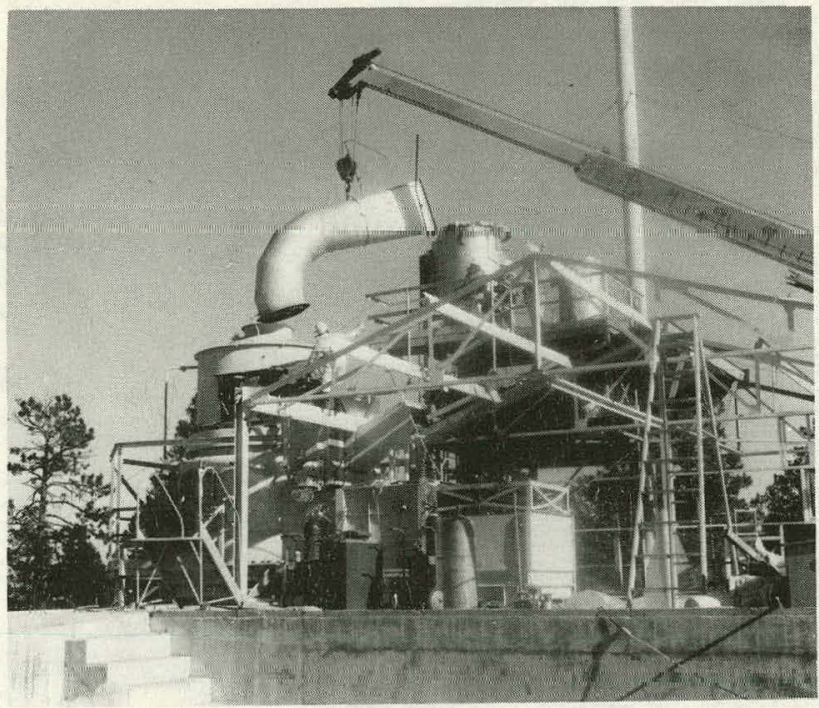

Fig. 9.

Crane supported and removed large items.

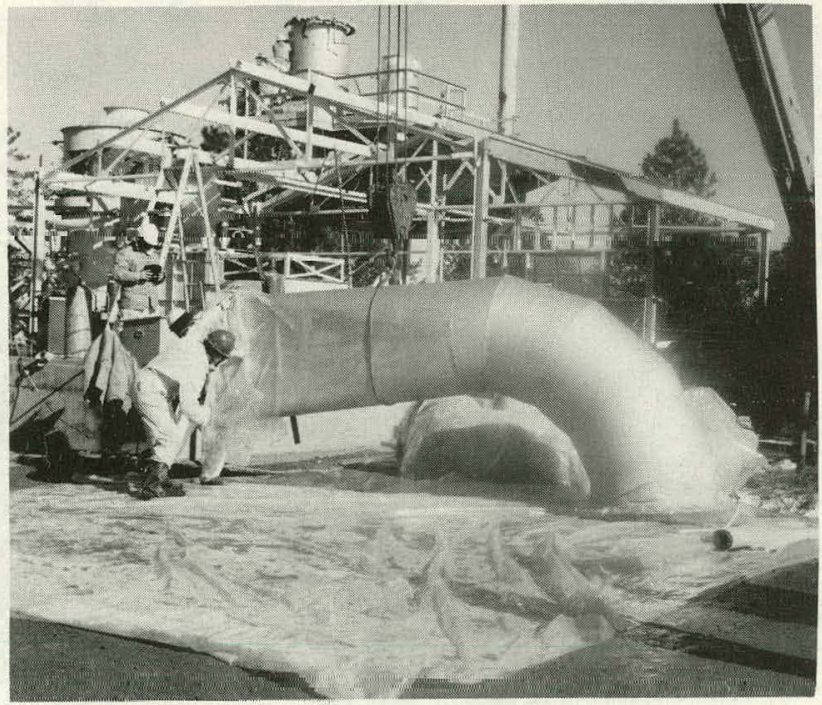

Fig. 10 .

Plastic sheets used to seal all openings. 


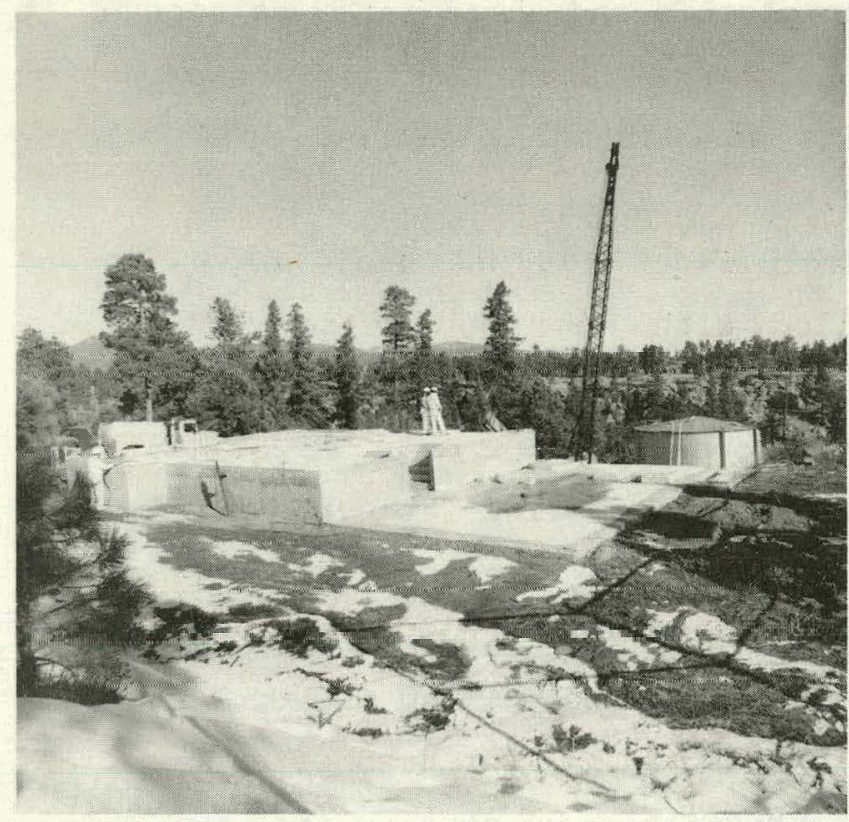

Fig. 11.

Bare concrete floor after removal of structures.

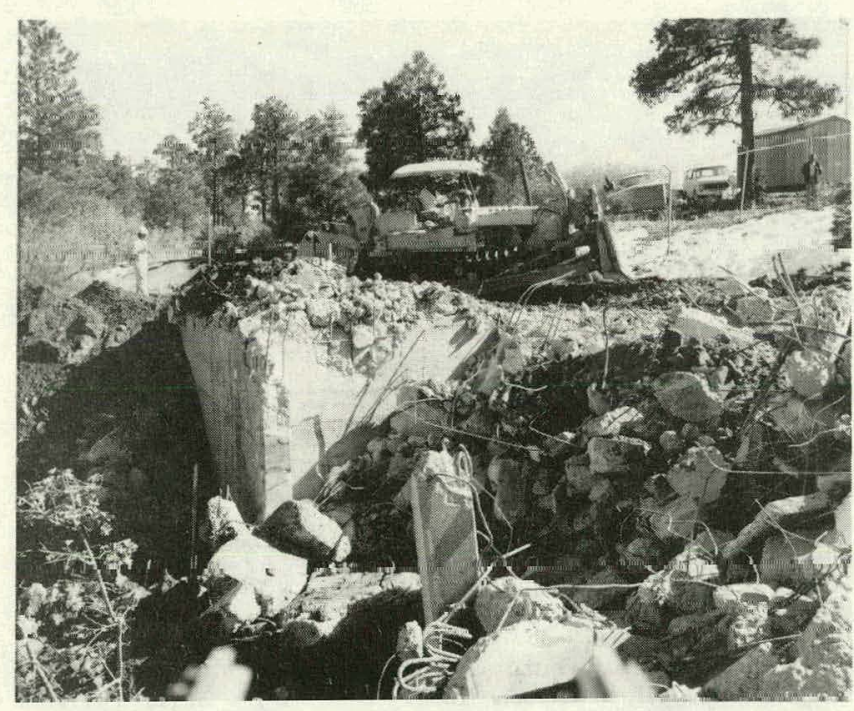

Fig. 13.

Bulldozer used to rip the foundation.

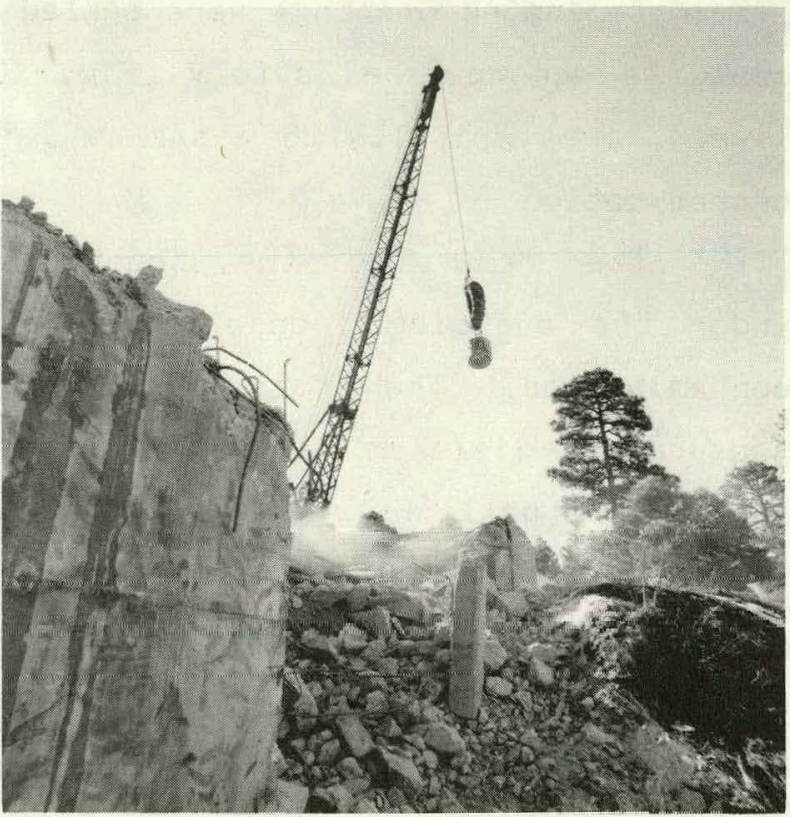

Fig. 12 .

Crane and steel ball used to crush foundation.

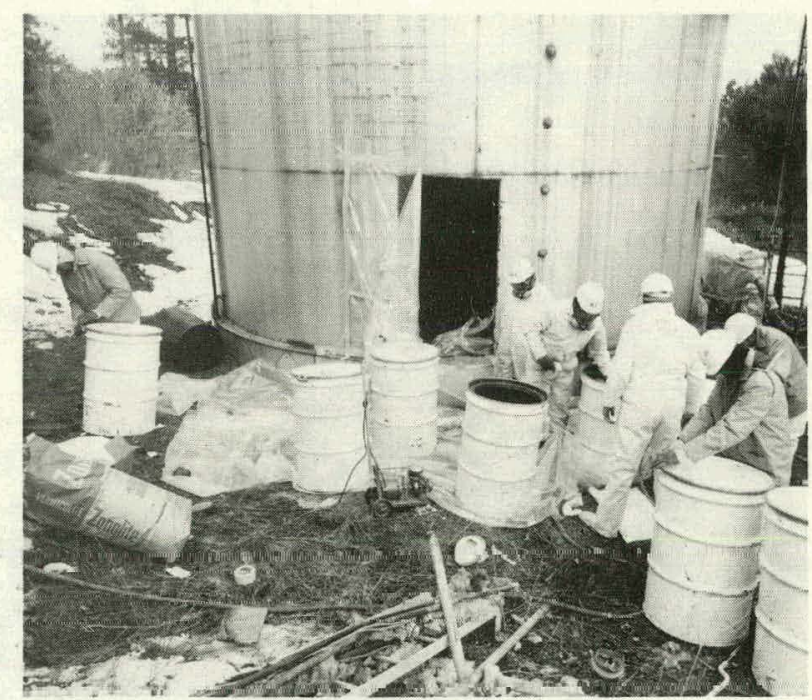

Fig. 14 .

Removal of dry sludge from ash storage tank. 


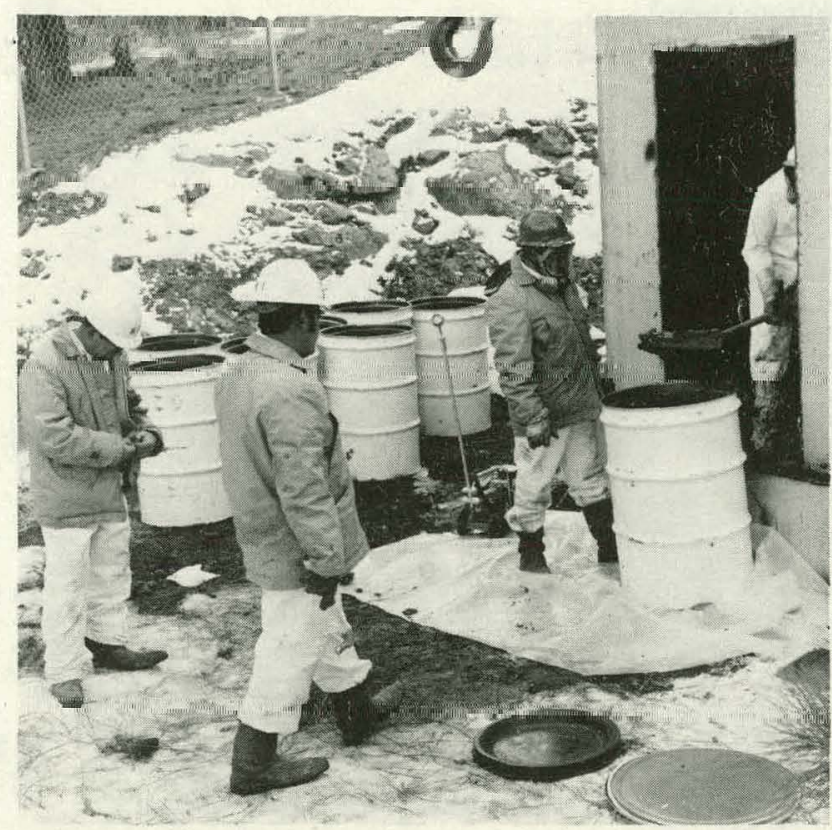

Fig. 15.

Removal of wet sludge from ash storage tank.

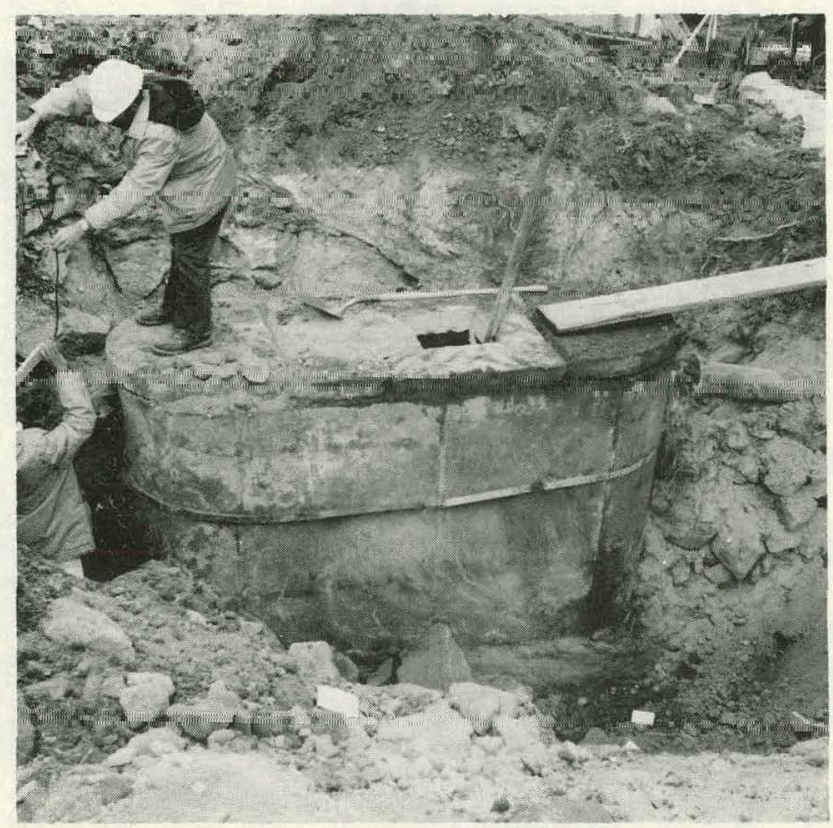

Fig. 16.

Concrete septic tank.

treatment facility. The 150 liters of sludge in the tank (containing $365 \mathrm{nCi}$ ${ }^{239} \mathrm{Pu}$ per gram of sludge) were solidified by the addition of cement. An attempt to remove the tank intact failed when the walls collapsed. The resulting rubble was loaded on a dump truck with a backhoe.

Three exploratory holes were augered (Fig. 17) into the septic tank tile field to establish contamination levels. Levels encountered indicated that the soil was not highly contaminated and could be removed by a backhoe, using water for dust control (Fig. 18). The gross alpha contamination was less than $1 \mathrm{nCi}$ per gram of soil.

The tile field drain pipe daylighted at the edge of a canyon. Phoswich surveys indicated general contamination in the immediate area. Migration of the contamination below the surface necessitated excavation of a pit area measuring $3.2 \mathrm{~m}$ wide, $3.8 \mathrm{~m}$ long, and $3.2 \mathrm{~m}$ deep at the canyon wall (Fig. 19). After soil removal operations were completed, the site was monitored for plutonium contamination. The levels encountered were determined to be as low as practicable. The site was then contoured to conform with the surrounding terrain and native grasses were planted (Fig. 20). 


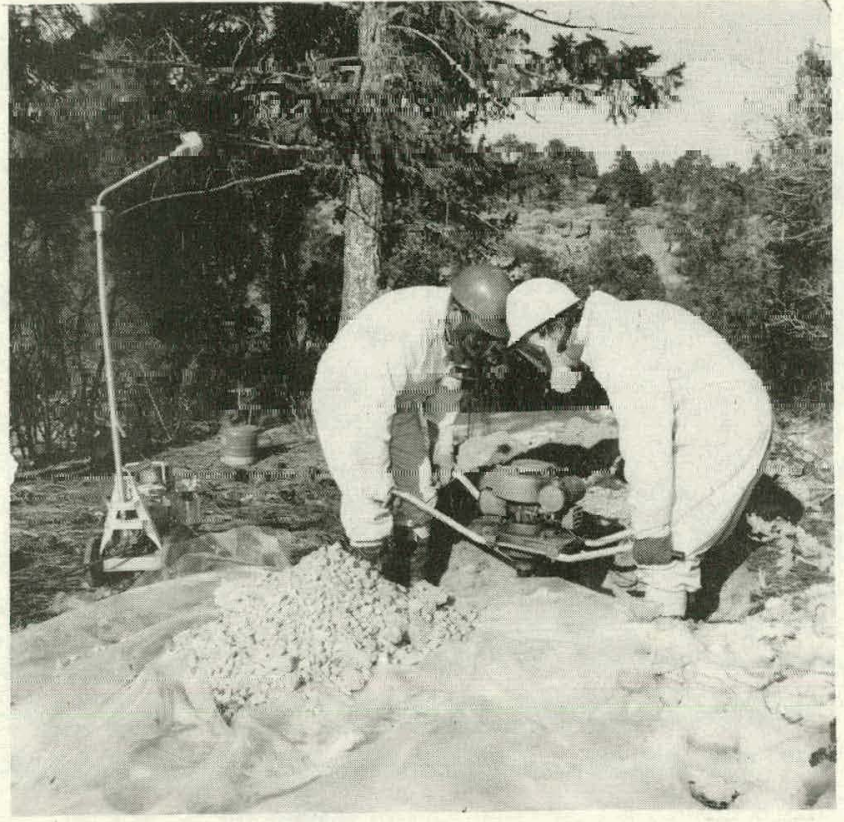

Fig. 17.

Exploratory holes augered into the septic tile field.

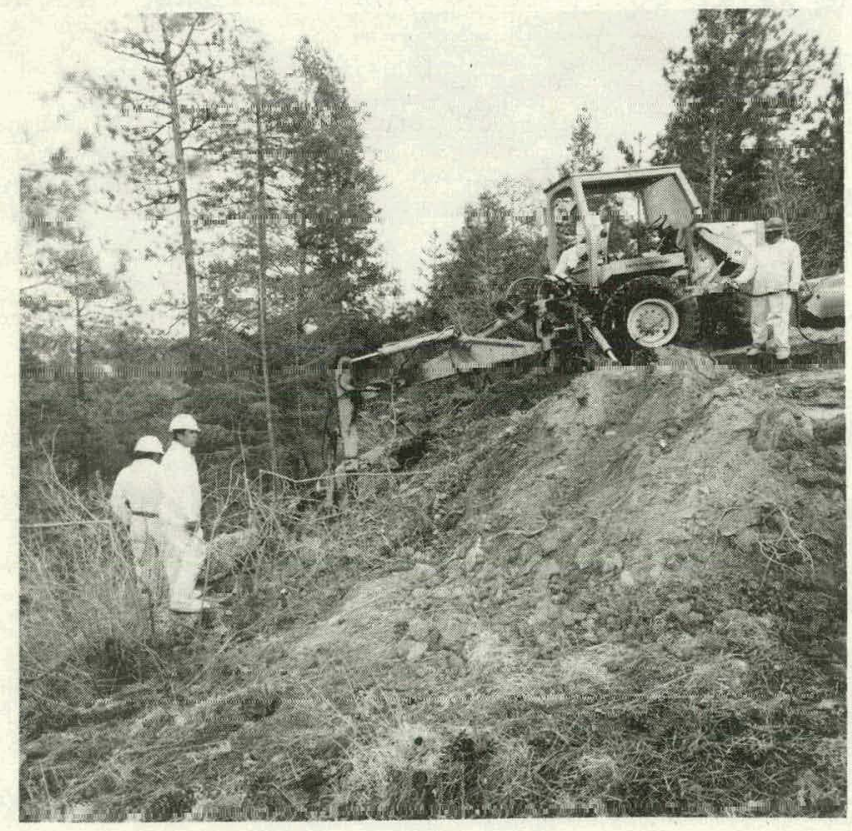

Fig. 19.

Soil excavation at edge of canyon wall.

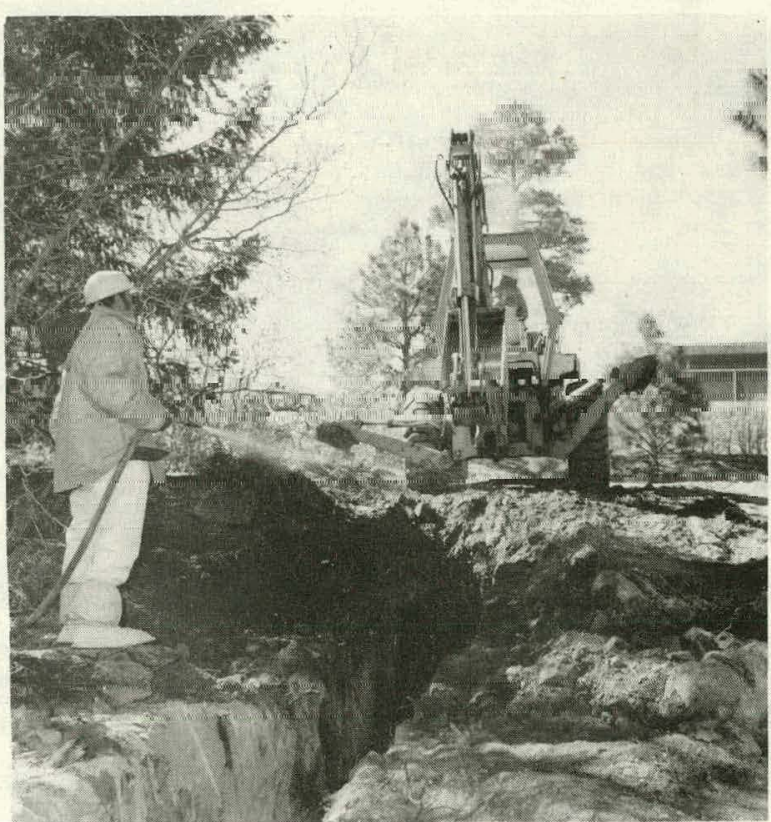

Fig. 18.

Water spray for dust control.

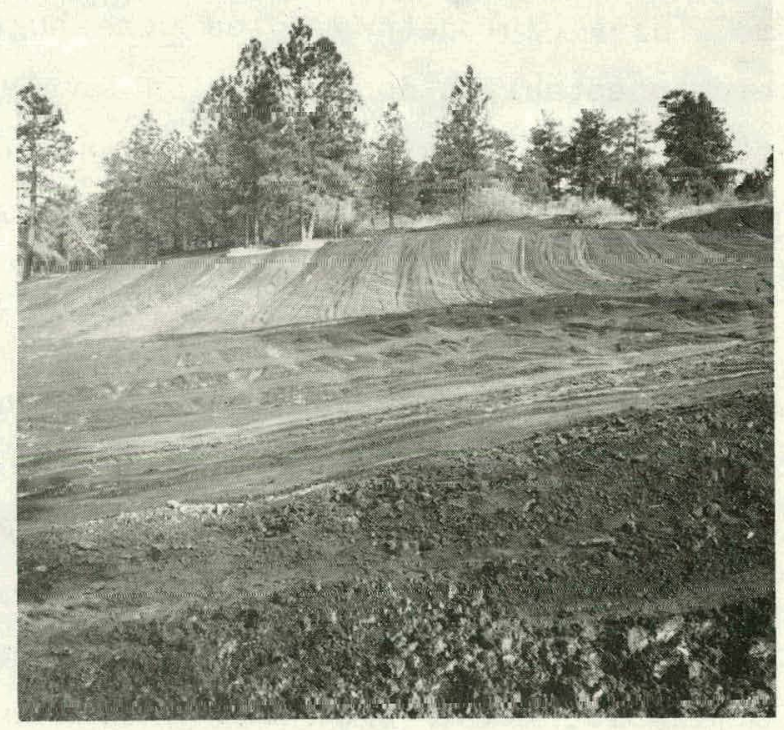

Fig. 20.

TA-42 Site after contouring and reseeding. 
III. HEALTH PHYSICS

Workers were provided protective (anticontamination) clothing for all work performed. This consisted of coveralls, gloves, and plastic booties. All workers also participated in a full-face respirator fitting, testing, and training program. Full-face respirators equipped with high-efficiency particulate filters were the standard respiratory protection during phases of demolition involving a potential for airborne contamination.

Air in the working area was sampled by passing it through an HV-70 filter paper at a rate of $1 \mathrm{l} / \mathrm{s}$. The paper was removed at the end of each work day and measured for alpha activity to provide a record of the workers' potential exposure to airborne contamination. On three occasions, the air concentrations were above background, with the highest concentration being $8.5 \times 10^{-2} \mathrm{dis} / \mathrm{s} / \mathrm{m}^{3}$. However, the workers were wearing respirators on all three occasions and nose swipes collected from each involved individual indicated no plutonium had been inhaled.

Urine samples were submitted by the workers at the beginning and completion of the project. No measurable plutonium body burden was indicated by the urinalysis program.

All personnel working on the project were provided with monthly beta-gamma and neutron film badges to record accumulated radiation exposures. Sixty-four of the 68 badges collected showed no exposure. The highest single monthly exposure recorded was 70 millirem. This exposure could not be entirely attributed to this project because the individual also worked at other job sites.

\section{WASTE MANAGEMENT}

All wastes generated by this operation were buried or stored at the Laboratory's TA-54 radioactive solid waste disposal/storage site, located $2.5 \mathrm{~km}$ from the decommissioning site. Six-hundred cubic meters of building debris and equipment and $1200 \mathrm{~m}^{3}$ of soil contaminated with less than $10 \mathrm{nCi}{ }^{239} \mathrm{Pu}$ per gram of waste were buried in trenches (Fig. 21). Contamination on equipment was measured with a Ludlum Model 139 alpha survey meter. Soil contamination was determined by sampling, drying, and measuring of gross alpha activity using a 


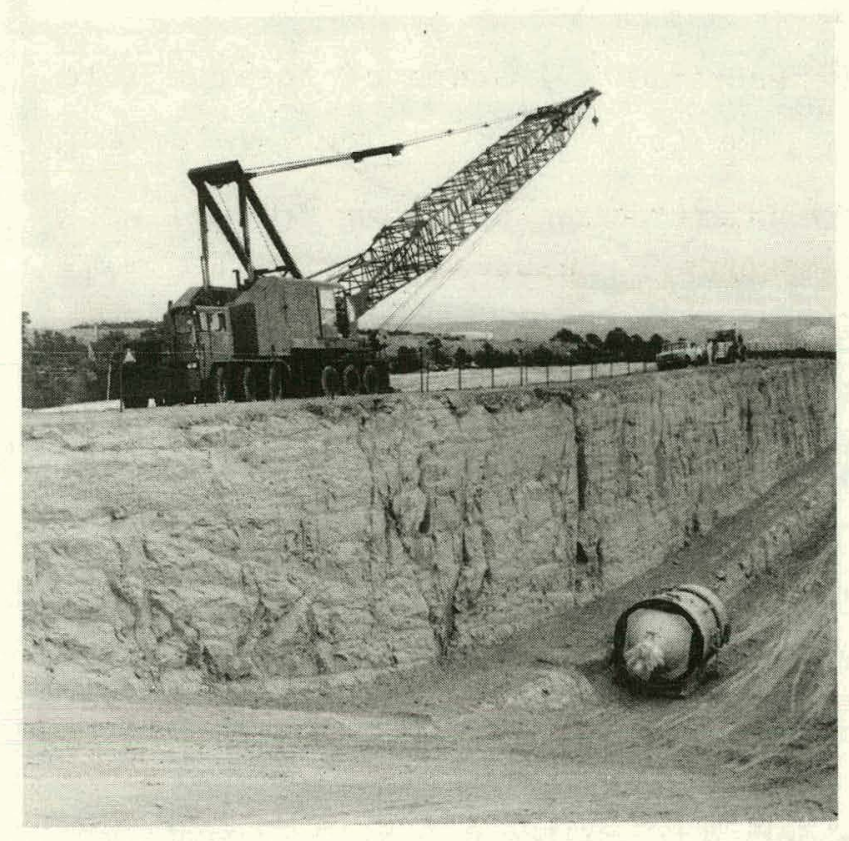

Fig. 21.

Disposal pit at the Los Alamos radioactive waste dispncal site.

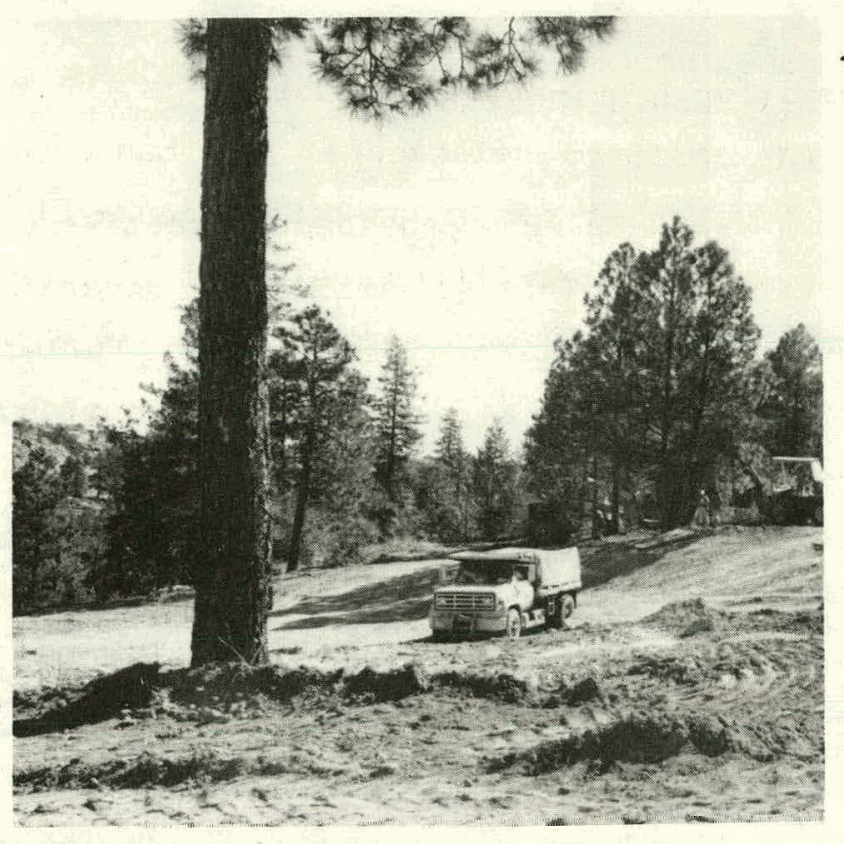

Fig. 22.

Transportation of waste was in tarpaulin-covếêl lump Lıucks.

zinc-sulfide scintillation system having a lower detection level of approximately 25 pCi gross alpha per gram of dry soil. 1

Sludges from the ash holding tanks were stored in containers meeting 20-year retrievability standards. They contained more than $10 \mathrm{nCi}{ }^{239} \mathrm{Pu}$ per gram of sludge. Approximately $4.5 \mathrm{~m}^{3}$ of sludge were packaged in twenty-three 200-liter storage containers equipped with 90-mil plastis inner liners. Theoc containers are retrievably stored at the waste disposal st.nrage site.

All wastes were transported in tarpaulin-covered dump or flat-bed trucks (Fig. 22). Trucks, loaders, and bulldozers used to load or transport contaminated materials were monitored during the job and decontaminated as necessary.

V. ENVIRONMENTAL SURVEILLANCE

The Laboratory's environmental surveillance personnel monitored the operation with its routine air sampling network ${ }^{2}$ and two additional nearby sampling stations. The DOE Concentration Guide (DOEM 0524) value for ${ }^{239}$ Pu was 
used for gross-alpha because it is the most restrictive isotope of the possible alpha emitters released at the Laboratory. The Concentration Guide value for ${ }^{131}$ I was used for gross-beta because it is the most restrictive isotope of the possible beta-emitters released at the Laboratory. Results of this sampling effort indicate no significant difference between the routine environmental surveillance net and the two special air samplers for this project (Tables I and II). Slightly elevated gross-beta concentrations occurred starting with the March 20 through March 27, 1978, sampling period for the routine airnet. These elevated activities were caused by fallout from the Chinese atmospheric nuclear test on March 14.

When an area was believed to be satisfactorily decontaminated, environmental surveillance technicians sampled for contamination. Final gross al pha contamination measurements indicated that.

a) 60 of 61 soil samples in the former building area contained less than $25 \mathrm{pCi}$ gross alpha per gram of soil ( $\mathrm{pCi} / \mathrm{g}$ ), one sample had a value of $29 \mathrm{pCi} / \mathrm{g}$ (Figs. 1 and 23 ):

\section{TABLE I}

AIR SAMPLING RESULTS FROM ROUTINE AIRNET

\begin{tabular}{|c|c|c|c|}
\hline Sampling Period & Location & $\begin{array}{c}\text { Average } \\
\text { Gross-Alpha } \\
(\mathrm{f} C \mathrm{C} / \mathrm{m} 3) \\
\end{array}$ & $\begin{array}{c}\text { Average } \\
\text { Gross-Beta } \\
\left(\mathrm{fCi} / \mathrm{m}^{3}\right) \\
\end{array}$ \\
\hline $12 / 17 / 77-1 / 16 / 78$ & $\begin{array}{l}\text { Regional } \\
\text { Perimeter } \\
\text { On-site }\end{array}$ & $\begin{array}{l}0.8 \pm 0.4 \\
1.4 \pm 0.6 \\
1.6 \pm 1.0\end{array}$ & $\begin{array}{l}67 \pm 12 \\
90 \pm 34 \\
98 \pm 36\end{array}$ \\
\hline $1 / 16 / 78-2 / 13 / 78$ & $\begin{array}{l}\text { Regional } \\
\text { Perimeter } \\
\text { On-site }\end{array}$ & $\begin{array}{l}1.1 \pm 0.6 \\
2.1 \pm 1.2 \\
2.9 \pm 2.0\end{array}$ & $\begin{array}{l}61 \pm 10 \\
84 \pm 31 \\
89 \pm 33\end{array}$ \\
\hline $2 / 13 / 78-3 / 13 / 78$ & $\begin{array}{l}\text { Regional } \\
\text { Perimeter } \\
\text { On-site }\end{array}$ & $\begin{array}{l}1.2 \pm 0.8 \\
2.7 \pm 1.6 \\
2.5 \pm 1.2\end{array}$ & $\begin{array}{l}140 \pm 36 \\
157 \pm 60 \\
163 \pm 57\end{array}$ \\
\hline $3 / 13 / 78-4 / 10 / 78$ & $\begin{array}{l}\text { Regional } \\
\text { Perimeter } \\
\text { On-site }\end{array}$ & $\begin{array}{l}1.2 \pm 0.8 \\
2.7 \pm 1.6 \\
2.5 \pm 1.2\end{array}$ & $\begin{array}{l}140 \pm 36 \\
157 \pm 60 \\
163 \pm 57\end{array}$ \\
\hline
\end{tabular}

a Three regional stations are $28-44 \mathrm{~km}$ distance from the Laboratory. Eleven perimeter stations are $0.4 \mathrm{~km}$ distance from the Laboratory. c Twelve stations are located within' the Laboratory environs. 
TABLE II

AIR SAMPLING RESULTS FROM SPECIAL AIRNET

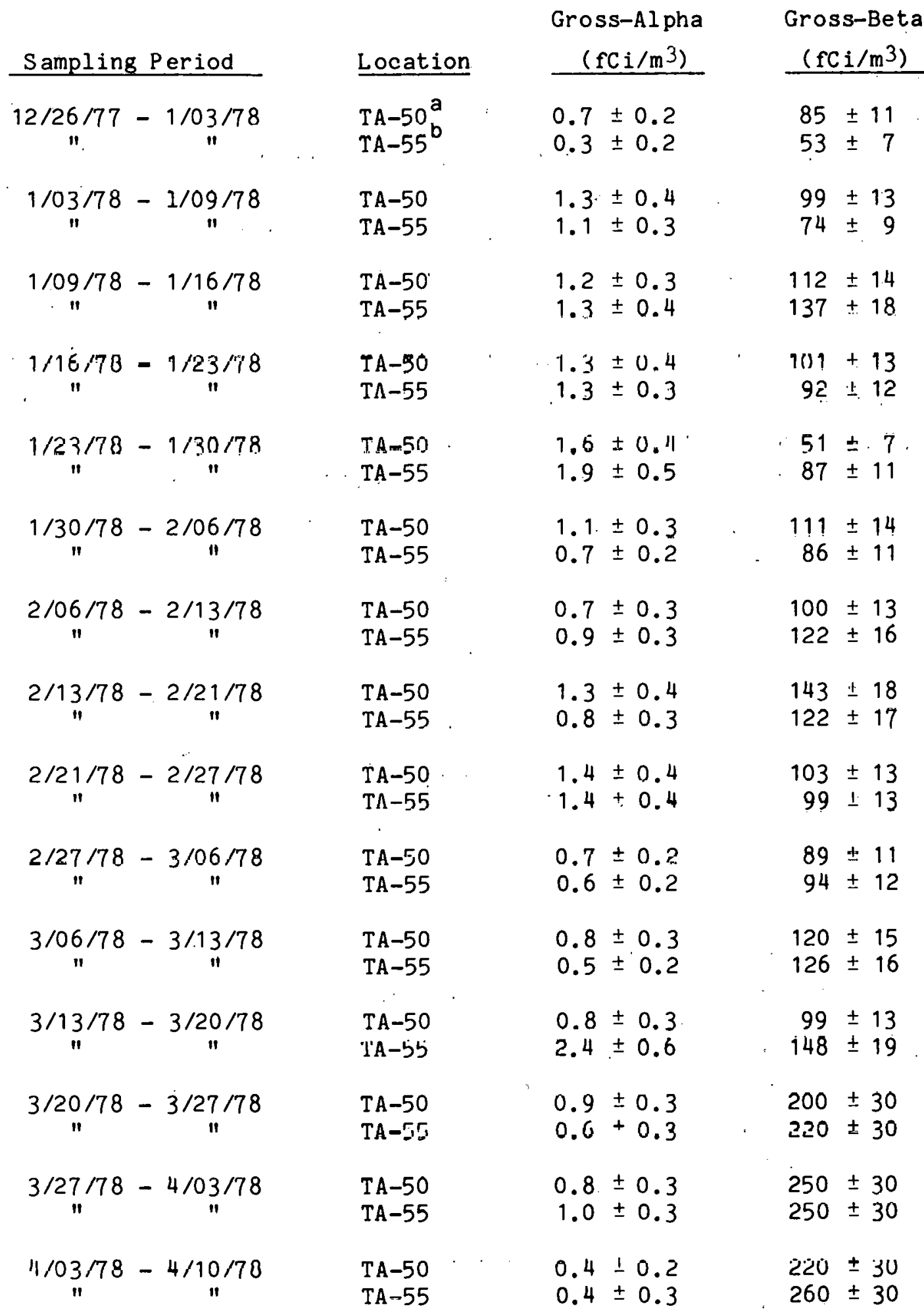

$a_{T A-50}$ is approximately $350 \mathrm{~m}$ southeast of TA-42.

$\mathrm{b}_{\mathrm{TA}-55}$ is approximately $40 \mathrm{~m}$ southwest of TA-42. 

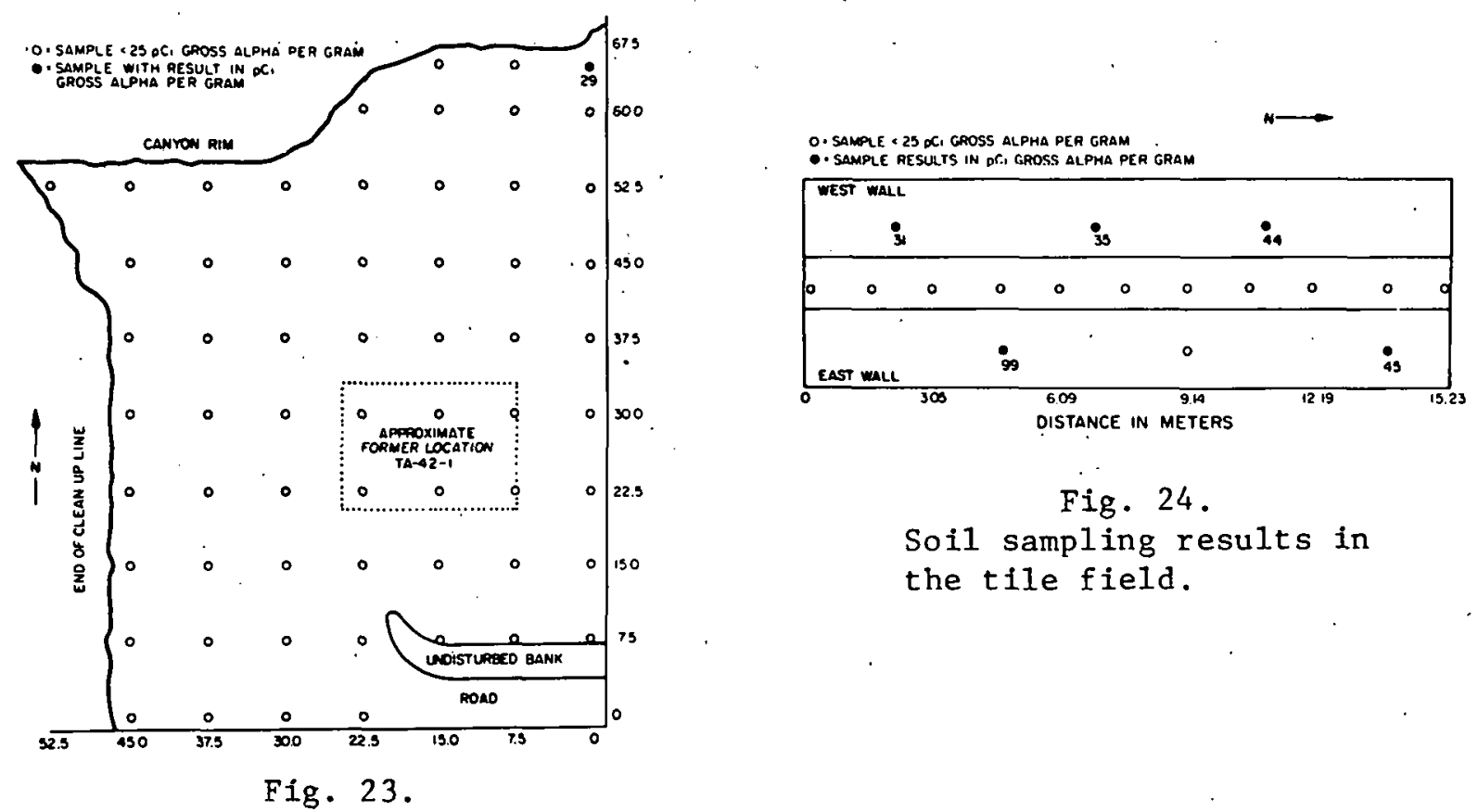

Fig. 24 .

Soil sampling results in the tile field.

Soil sampling results of formerly

fenced area. The grid is in meters.

b) all samples in the septic tank area had a value of less than $25 \mathrm{pCi} / \mathrm{g}$;

c) four of 17 samples in the tile field were greater than $25 \mathrm{pCi} / \mathrm{g}$; the highest being $99 \mathrm{pCi} / \mathrm{g}$ (Figs. 1 and 24); and

d) five of eight samples in the excavation under the tile field drain outfall were less than $25 \mathrm{pCi} / \mathrm{g}$; the highest being $418 \mathrm{pCi} / \mathrm{g}$ (Figs. 1 and 25).

Because of the low lcvele (Fig. 26) of nont.amination and the safety hazards associated with any further excavation, the Environmental Surveillance Group considered the area decontaminated to as low as reasonably achievable (ALARA). After concurrence from the Laboratory's Health Division office and the Los Alamos, New Mexico, Area Office of the U.S. Department of Energy (Appendix), the area was contoured and revegetated to minimize erosion (Fig. 21).

VI. $\cos T S$

Eighty working days were required to complete the project at a total cost of $\$ 150$ 000. Laboratory subcontractor support for operational manpower and 
equipment costs were totaled as $\$ 85000$ and direct Laboratory support costs were $\$ 65$ 000. Table III presents a breakdown of subcontractor support by craft manhours.

TABLE III

\section{SUBCONTRACTOR CRAFTS SUPPORT}

\begin{tabular}{lr}
\multicolumn{1}{c}{ Craft } & Total Manhours \\
\hline Laborers & 2457 \\
Teamsters & 692 \\
Painters & 100 \\
Operating Engineers & 666 \\
Ironworkers & 273 \\
Sheet Metal Workers & 30 \\
& \\
Total & 4168
\end{tabular}

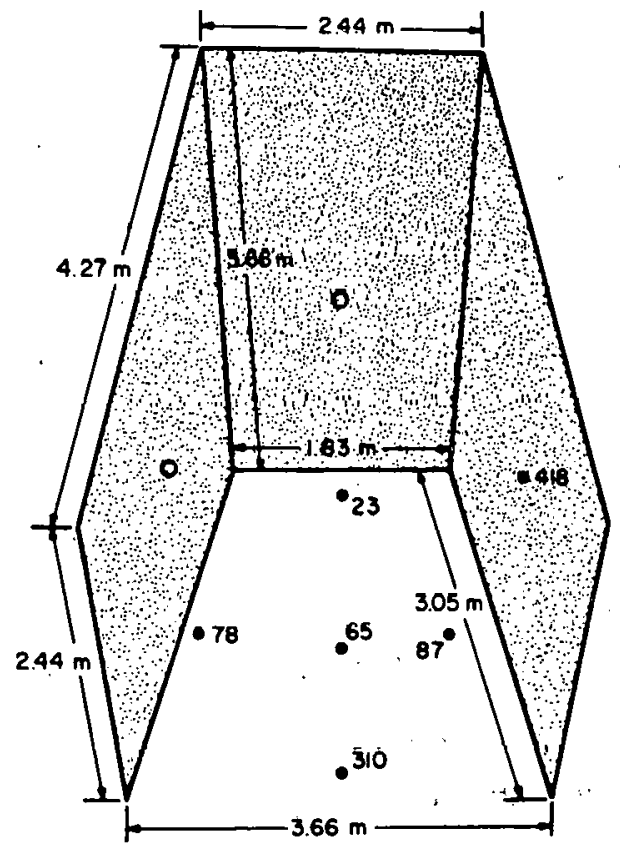

$0=$ SAMPLE $<25$ pCi GROSS ALPHA PER GRAM - SAMPLE RESUlt IN pCi gRoss alpha PER gRaM

Fig. 25 .

Soil sampling results in the excavated "PIT." under the tile field outfall.

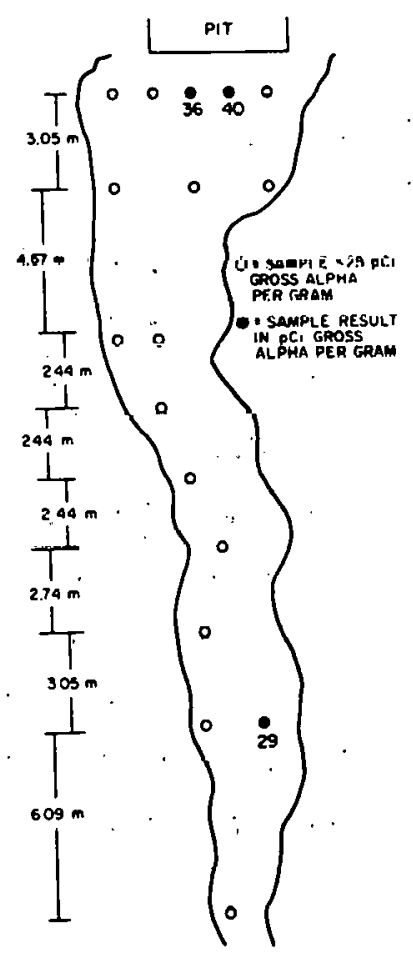

Fig. 26.

Soil sampling results on the canyon wall. The "PIT" is the area below the tile field outfall. 


\section{REFERENCES}

1. A. J. Ahlquist, C. J. Umbarger, and A. K. Stoker, "Recent Developments for Field Monitoring for Alpha Emitting Contaminants in the Environment," Health Physics 34 , No. 5, 486 (1978).

2. Environmental Studies Group, "Environmental Surveillance at Los Alamos During 1976," Los Alamos Scientific Laboratory report LA-6801-MS (April 1977). 
DEPARTMENT OF ENERGY

Los Alamos, New Mexico 87544

Harry S. Jordan, Assistant Division Leader

for Oporationo, II-Division, LA3L (MdII Stup 400)

DECONTAMINATION - TA-42

I reviewed the memorandum (and the attached five figures),

from A. John Ahlquist, H-8, to Ray Garde, H-1, dated May 9

1978, and I toured the TA-42 area on July 10, 1978, with

Ray Garde, and I concur in the LASL recommendation that

all areas associated with the TA-42 site be considered to

have been decontaminated to ALAP (as low as practicable).

Please call if you have questions.

Original Signed By:

W. CRISMON, JR.

William Crismon, Jr. Chief

Technical Programs Branch.

LTP : WC

cc: Kay Garde, H-1, LASL

(Ma11 Ștop 401)

APPENDTX

REPRODUCTION OF THE LAAO ALARA CONCURRENCE 


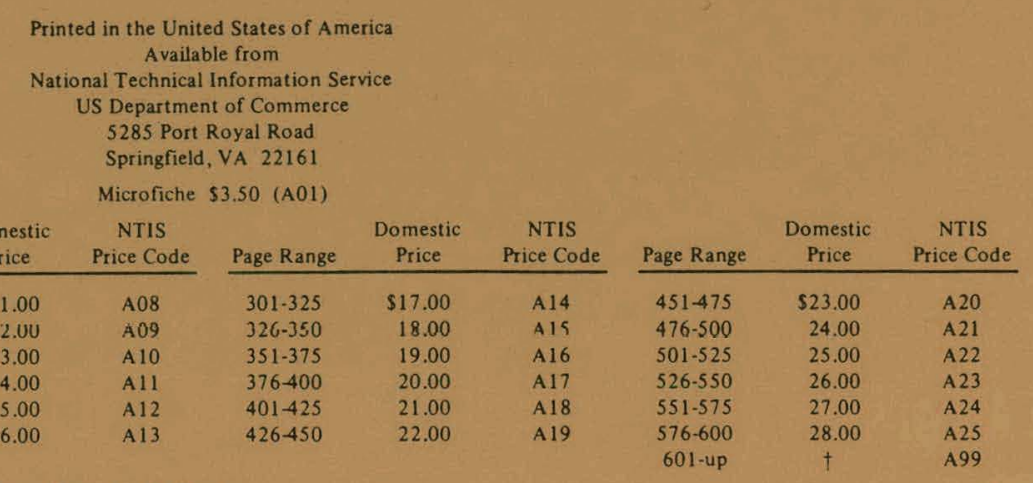

†Add $\$ 1.00$ for each additional 25-page increment or portion thereof from 601 pages up. 


\section{LOS Alamos}

